\title{
Post-COVID-19 Syndrome? New daily persistent headache in the aftermath of COVID-19
}

\author{
Síndrome Pós-COVID-19? Nova cefaleia diária persistente após COVID-19 \\ Jonathan Wei Ting Wen LIU1', Renata D'altoé DE LUCA', Heraldo Oliveira MELLO NETO², Igor BARCELLOS
}

\section{Dear Editor,}

We read with great interest the systematic review article entitled "Neurological complications in patients with SARS-CoV-2 infection: a systematic review" by Munhoz et al ${ }^{1}$, published in this journal in May 2020. We want to congratulate the authors for this successful article and add our own contributions.

Recently, we noticed frequent clinical visits (General Neurology Outpatient Clinic and a Radiology Clinic) with complaints suggestive of New Daily Persistent Headache (NDPH) following recovery from SARS-CoV2 infection, which is characterized by a clear and distinct onset, persistent headache. It is known that extracranial viral infections are the main triggering factor of NDPH, in addition to stressful life events and invasive procedures such as intubation².

Headache is a frequent symptom associated with ongoing SARS-CoV2 infection, as reported by Munhoz et al. (up to 34\%); however, headache persistence has been observed even weeks after recovery ${ }^{3}$, and as described in case reports and in the authors' experience, enough to fulfill International Classification of Headache Disorders, 3rd edition (ICHD-3 ), diagnostic criteria for NDPH. To our knowledge, there is still no comprehensive review of remote morbidities following recovery.

In our experience, the following patterns were agreed upon: they had mild or moderate respiratory symptoms, treated on an outpatient basis, mainly without a diagnosis of pre-existing primary headache, had characteristics of holocranial, pressure-like pain starting within 2 weeks after recovery of respiratory symptoms, no pathological causal findings have been observed in contrasted imaging studies (excluding cerebral venous thrombosis, a known neurological complication of SARS-COV2 infection).

The pathophysiology of NDPH is largely unknown, some studies believe that the pain may be due to the production of cytokines and persistent glial activation that arise in response to precipitating events ${ }^{4}$, which is also one of the hypotheses for CNS involvement by COVID-19, thus occurring synergy between pathophysiological mechanisms.

In clinical practice, most headache specialists treat NDPH based on the main headache phenotype, whether it is migraine or tension-type. No medication has shown to be advantageous in the studies conducted to date. As such, prophylactic treatment was used mostly with a tricyclic antidepressant or anticonvulsant (namely, amitriptyline and topiramate), with varying success ${ }^{4,5}$.

In our opinion, as we follow an increasing number of patients recovered after SARS-CoV-2 infection, a better understanding of the pathophysiology and course of the disease (and therefore the best treatment approach) is certainly warranted.

\section{References}

\footnotetext{
1. Munhoz RP, Pedroso JL, Nascimento FA, Almeida SM de, Barsottini OGP, Cardoso FEC, et al. Neurological complications in patients with SARS-CoV-2 infection: a systematic review. Arq Neuropsiquiatr. 2020 May;78(5):290-300. https://doi.org/10.1590/0004$282 \times 20200051$

2. Li D, Rozen TD. The clinical characteristics of new daily persistent headache. Cephalalgia. 2002 Feb 1;22(1):66-9. https://doi. org/10.1046/j.1468-2982.2002.00326.x
}

3. Sampaio Rocha-Filho PA, Voss L. Persistent headache and persistent anosmia associated with COVID-19. Headache. 2020 Aug;60(8):17979. https://doi.org/10.1111/head.13941

4. Yamani N, Olesen J. New daily persistent headache: a systematic review on an enigmatic disorder. J Headache Pain. $2019 \mathrm{Jul}$ 15;20(1):80. https://doi.org/10.1186/s10194-019-1022-z

5. Rozen TD. New daily persistent headache. Curr Pain Headache Rep. 2003 May;7(3):218-23. https://doi.org/10.1007/s11916-003-0076-3

\footnotetext{
${ }^{1}$ Hospital Universitário Cajuru, Department of Neurology, Curitiba PR, Brazil.

${ }^{2}$ Clínica X-LEME Diagnóstico por Imagem, Curitiba PR, Brazil.

Jonathan Wei Ting Wen LIU (iD https://orcid.org/0000-0003-0388-4254; Renata D'altoé DE LUCA (iD) https://orcid.org/0000-0001-7455-8208; Heraldo Oliveira MELLO NETO (D) https://orcid.org/0000-0003-1307-5071; Igor BARCELLOS (D) https://orcid.org/0000-0003-1502-7604

Correspondence: Jonathan Wei Ting Wen Liu; E-mail: jonathan.weiting@gmail.com.

Conflict of interests: There is no conflict of interests to declare.

Authors' contribution: JWTL and RDL wrote the original draft, HOMN and IB reviewed, edited and supervised the paper. All authors reviewed the final manuscript. Received on September 30, 2020; Received in its final form on November 12, 2020; Accepted on October 1, 2020.
} 


\section{Reply}

\section{Resposta}

Renato Puppi MUNHOZ1, José Luiz PEDROSO², Fábio Augusto NASCIMENTO³, Sergio Monteiro DE ALMEIDA4, Orlando Graziani Povoas BARSOTTINI², Francisco Eduardo Costa CARDOSO ${ }^{5}$, Hélio Afonso Ghizoni TEIVE ${ }^{6}$

We thank Dr. Liu and colleagues for their comments and citation of our systematic review ${ }^{1}$ apropos of their insightful clinical observation presented in the letter entitled Post-COVID-19 Syndrome? New daily persistent headache in the aftermath of COVID-192.
This description of a potentially new late complication of SARS-CoV-2 infection confirms a previous similar observation ${ }^{3}$ and provides a reasonable pathophysiological rationale as well as a treatment approach. We congratulate the authors for their astute clinical observation, which may serve as guidance and advice for the clinician involved in the care of these patients.

\section{References}

1. Munhoz RP, Pedroso JL, Nascimento FA, De Almeida SM, Barsottini OGP, Cardoso FEC, et al. Neurological complications in patients with SARS-CoV-2 infection: a systematic review. Arq Neuropsiquiatr. 2020 May;78(5):290-300. https://doi.org/10.1590/0004$282 \times 20200051$
2. Liu JWTW, De Luca RD, Mello Neto HO, Barcellos I. Post-COVID-19 Syndrome? New daily persistent headache in the aftermath of COVID-19. Arq. Neuropsiquiatr. 2020. In Press.

3. Sampaio Rocha-Filho PA, Voss L. Persistent headache and persistent anosmia associated with COVID-19. Headache. 2020 Sep 26;60(8):1797-9. https://doi.org/10.1111/head.13941

\footnotetext{
'University of Toronto, Toronto Western Hospital, Movement Disorders Centre, Toronto ON, Canada.

¿Universidade Federal de São Paulo, Escola Paulista de Medicina, Department of Neurology and Neurosurgery, São Paulo SP, Brazil.

${ }^{3}$ Baylor College of Medicine, Department of Neurology, Houston TX, USA.

${ }^{4} U$ niversidade Federal do Paraná, Hospital de Clínicas, Neuroinfection Outclinic, Virology Laboratory, Medical Pathology Department, Curitiba PR, Brazil.

${ }^{5}$ Universidade Federal de Minas Gerais, Hospital das Clínicas, Movement Disorders Unit, Neurology Service, Internal Medicine Department, Belo Horizonte MG, Brazil.

${ }^{6}$ Universidade Federal do Paraná, Hospital de Clínicas, Internal Medicine Department, Neurology Service, Curitiba PR, Brazil.

Renato Puppi MUNHOZ (DD http://orcid.org/0000-0002-4783-4067; José Luiz PEDROSO (D) http://orcid.org/0000-0002-1672-8894;

Fábio Augusto NASCIMENTO3 (i) http://orcid.org/0000-0002-7161-6385; Sergio Monteiro DE ALMEIDA4 (D) http://orcid.org/0000-0001-5690-105X;

Orlando Graziani Povoas BARSOTTINI² (D) http://orcid.org/0000-0002-0107-0831; Francisco Eduardo Costa CARDOSO5 (D) http://orcid.org/0000-0003-0808-0116; Hélio Afonso Ghizoni TEIVE6 ${ }^{6}$ (D) http://orcid.org/0000-0003-2305-1073

Correspondence: Renato Puppi Munhoz; E-mail: renato.munhoz@uhn.ca.

Conflict of interests: There is no conflict of interests to declare.

Authors' contribution: RPM: drafting of the manuscript. JLP, FAN, SMA, OGPB, FECC, and HAGT: manuscript review.

Received on October 2, 2020; Received in its final form; November 9, 2020; Accepted on October 5, 2020.
} 